\title{
THE EFFECTS OF TOXIC AGENTS UPON THE ACTION OF BROMELIN.
}

\author{
CONTRIBUTIONS FROM THE HULL BOTANICAL LABORATORY. \\ LXXIII.
}

JOSEPH STUART CAL DWELL.

\section{HISTORICAL.}

Attention was first directed to the existence of a proteolytic enzyme in the juice of the pineapple (Ananas sativus) by Marcano (13). It was called bromelin by Chittenden, who, with his pupils, examined it in some detail $(\mathbf{3}, \mathbf{4})$. They prepared it from the expressed and filtered juice, after neutralization, by saturation with crystals of ammonium or magnesium sulfate or sodium chlorid, any of which precipitate the enzyme together with some proteid matter. The precipitate was dialyzed free from salt in running water, collected upon a filter, and dried at $40^{\circ} \mathrm{C}$. upon a water-bath. The flaky, whitish residue thus obtained consisted of the enzyme with some associated proteid. It was soluble in water and active in acid or neutral solutions, very slightly or not at all in an alkaline medium. The sodium chlorid preparation was more active and greater in amount than the others, and was used throughout the experiments. CHITTENDEN'S study was directed principally to a determination of the products of digestion of blood-fibrin, myosin, and coagulated egg albumen. These were found to be hemi- and anti-peptones, proto-, hetero-, and deutero-proteose, leucin, and tyrosin. The enzyme was thus determined to be tryptic in nature, and akin to other vegetable trypsins in that it acted best in an acid medium.

PURPOSE.

The experiments described in this paper were undertaken with a view to ascertaining whether a similarity existed between the effects of poisonous metals upon the action of an enzyme and those observed in experiments upon living organisms. While an immense amount of work has been done with plants and animals, the results are at variance, not even agreeing as to the most poisonous metal. I005]

409 
It was hoped that the limits of toxicity might be more clearly defined in the case of enzymes.

Very little work has been done in this field. In a general way it is known that slight amounts of metallic salts affect enzymic action. Coles (6) found that cations and hydroxyl ions depress and anions accelerate the action of ptyalin and invertin. Results with acids and alkalis vary with the enzyme used $(\mathbf{7}, \mathbf{8}, \mathbf{r o})$. So far as I am able to ascertain, the only extended work with poisonous metals has been that of McGuigan (I6) upon diastase. His results confirm the theory advanced by Mathews (Io, II) that the physiological action of any atom or ion depends primarily upon its affinity for its electrical charge. The work described in this paper was undertaken with a view to determining whether this theory would hold for a tryptic enzyme, and was completed before MGGuigan's results were known to me.

Bromelin was chosen as a typical vegetable trypsin, rapid in its action, easily prepared, and hitherto studied only with reference to its digestion-products and its action in the presence of acids and alkalis.

\section{PREPARATION OF THE ENZYME.}

It was desirable to prepare the enzyme in as pure a state as possible, since it was early found that the presence of associated proteid matter obscured the results of my experiments. Even very slight amounts apparently shielded the enzyme from the action of poisons. Furthermore, it was shown by some preliminary experiments, summarized elsewhere in this paper, that autodigestion, with the formation of peptones, leucin, and tyrosin, occurred in solutions of the impure enzyme when kept for some time at temperatures between 25 and $65^{\circ} \mathrm{C}$.

After several trials, a preparation was obtained which contained only very slight traces of associated proteid, and which was not at all autodigestive. The dialyzed $\mathrm{NaCl}$-precipitate was dissolved in a little water, reprecipitated by the addition of 95 per cent. alcohol, again dissolved in water, and again precipitated by adding crystals. of $\left(\mathrm{NH}_{4}\right)_{2} \mathrm{SO}_{4}$. A little of the associated proteid is left behind at every precipitation, and five repetitions of the process gave a preparation containing only slight traces of proteid. Precipitation was. much hastened by placing the vessel in the refrigerator at about $4^{\circ} \mathrm{C}$. 
After being dried upon the water-bath at $40^{\circ} \mathrm{C}$., the preparation was wholly soluble in water and was not autodigestive in any medium even after prolonged standing. It was active in faintly acid or alkaline solutions, though not at all in neutral media. This preparation was used throughout the experiments.

In order that the results might not be rendered inaccurate through the use of preparations of unequal purity, all the enzyme used was prepared at one time and thoroughly mixed after drying. From 46 pineapples of average size, $16.4^{\mathrm{kg}}$ of filtered juice were obtained, which yielded $\mathrm{I} 4.8^{\mathrm{gm}}$ of the enzyme dried at $40^{\circ} \mathrm{C}$. This was kept in a calcium chlorid desiccator and from time to time compared with fresh preparations, but no deterioration occurred in the period covered by the experiments.

The enzyme was most active in solutions of alkalinity equaling $m / 30-m / 40 \mathrm{NaOH}$, and was considerably less active in acid solutions irrespective of strength. Its action was wholly inhibited by $m /$ Io $\mathrm{HNO}_{3}$ or $\mathrm{H}_{2} \mathrm{SO}_{4}, m / \mathrm{I}_{5} \mathrm{HCl}, \mathrm{NaOH}$, or $\mathrm{KOH}$, or $m / 20 \mathrm{NH}_{4} \mathrm{OH}$.

The fact that the enzyme had been found most active in acid and neutral solutions by CHItTEnden, while my own preparations were markedly more active in alkaline than in acid media and showed only the slightest trace of activity in neutral solutions, led me to a very careful examination of this point. Chitrenden's statement of his method was followed in making a number of preparations. Pineapples of varying ripeness were chosen, upon the hypothesis that a change in the nature of the enzyme might occur with the ripening of the fruit, but all of my preparations agreed perfectly in requiring an alkaline medium for optimum action, very much less action occurring in acid media. One preparation from very immature fruits showed faint activity in a neutral solution. This difference from the results of ChitTendeN's examination seems explicable only on the ground that I have misunderstood his statement of his method of preparation; yet the method is simple and the statement is apparently lucid and exact enough to be followed without difficulty.

ISOLATION OF THE ALKALINE ENZYME.

Some of the facts observed in the preparation of the enzyme suggested that it might be in reality a mixture of two enzymes separ- 
able by proper treatment. Some experiments with this purpose in view met with partial success.

A neutral solution of one gram of the dry enzyme in $100^{\mathrm{cc}}$ water was carefully heated to $65^{\circ} \mathrm{C}$. Upon gradual addition of $\mathrm{NaCl}$ crystals a slight precipitate settled out, which when collected by filtering, and dried, weighed $0.3^{\mathrm{gm}}$. The filtered liquid when freed from $\mathrm{NaCl}$ showed no activity upon egg-albumen in acid solutions, regardless of strength, but its activity in alkaline solutions was undiminished and accorded in all respects with that of ordinary preparations of the enzyme in alkaline media, the products of digestion with the two being identical. The heat precipitate was imperfectly soluble in water and showed no action upon egg-albumen in any medium.

I believe that these facts, with the differences, elsewhere stated, in the action of poisons upon acid and alkaline solutions of the enzyme, justify the conclusion that there are present in the preparation two enzymes, one active in acid, the other in alkaline solutions. I am aware that full proof of this statement demands isolation of the acidenzyme without destroying it in the process, but this I am as yet unable to do.

That the presence of $\mathrm{NaCl}$ is a necessary condition for the precipitation of the acid-enzyme is shown by the fact that no precipitation occurs in unsalted solutions until heated to $76^{\circ} \mathrm{C}$., activity in both acid and alkaline media being retained until complete precipitation occurs at $87-90^{\circ}$.

\section{EXPERIMENTS WITH POISONS.}

In the experiments with poisons, solutions containing $0.006^{\mathrm{gm}}$ of the enzyme per cubic centimeter were made up with distilled water previously made acid or alkaline by the addition of $\mathrm{HCl}$ or $\mathrm{NaOH}$. An $m / 32$ acid or alkali was adopted as a medium for all digestions, since this strength allowed optimum activity in each case. Thymol was used to prevent bacterial infection and was found perfectly satisfactory. Of this solution $5^{\mathrm{cc}}$, containing $0.03^{\mathrm{gm}}$ of the enzyme, were transferred to each of the test-tubes to be used. To each was then added $5^{\mathrm{cc}}$ of the poison to be used, of twice the desired strength, i.e., $5^{\text {cc }}$ enzyme solution plus $5^{\mathrm{cc}} \mathrm{m} / 5000 \mathrm{Ba}\left(\mathrm{NO}_{3}\right)_{2}$ gives 
${ }_{10}{ }^{c c} \mathrm{~m} / \mathrm{I} 0000 \mathrm{Ba}\left(\mathrm{NO}_{3}\right)_{2}$. To each tube was then added $\mathrm{I}^{\mathrm{gm}}$ eggalbumen previously boiled and granulated, and the tubes were then placed in the water-bath at $40^{\circ} \mathrm{C}$. for 24 hours. They were then removed, filtered to remove undissolved albumen, and tested.

Tests were made for peptones, leucin, and tyrosin by all the standard tests. The biuret reaction after precipitation of the albumoses, and the tryptophan reaction described by Vines $(\mathbf{2 5}, d)$ were

\begin{tabular}{|c|c|c|c|c|}
\hline \multirow{3}{*}{ SALT } & \multirow{2}{*}{\multicolumn{2}{|c|}{$\frac{\text { OPTIMUM ACID MEDIUM } m / 32 \mathrm{HCl}}{\text { Dilution of molecular solution }}$}} & \multirow{2}{*}{\multicolumn{2}{|c|}{$\begin{array}{c}\frac{{ }_{\text {OPTIMUM ALKALINE MEDIUM }}}{m / 32 \mathrm{NaOH}} \\
\text { Dilution of molecular solution }\end{array}$}} \\
\hline & & & & \\
\hline & Inhibiting & Allowing & Inhibiting & Allowing \\
\hline 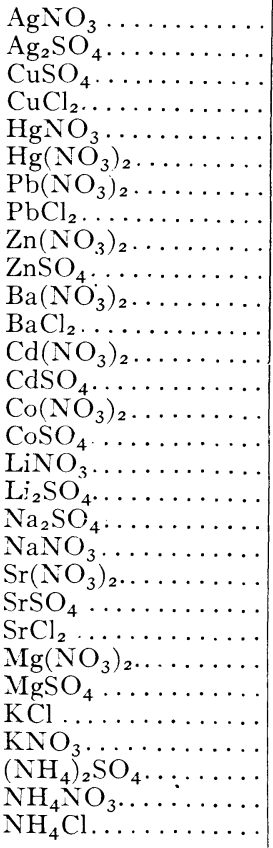 & $\begin{array}{r}\text { II } 10,000 \\
80,000 \\
60,000 \\
48,000 \\
75,000 \\
65,000 \\
40,000 \\
37,500 \\
28,000 \\
\text { I6,750 } \\
\text { I0,000 } \\
8,000 \\
6,000 \\
4,800 \\
4,800 \\
4,500 \\
\text { I,000 } \\
750 \\
512 \\
\text { I,600 } \\
900 \\
750 \\
800 \\
650 \\
600 \\
100 \\
100 \\
256 \\
400 \\
320\end{array}$ & $\begin{array}{r}\text { I } 30,000 \\
\text { I I0,000 } \\
90,000 \\
70,000 \\
90,000 \\
85,000 \\
60,000 \\
56,000 \\
32,000 \\
23,000 \\
\text { I } 3,000 \\
\text { I } 2,000 \\
7,600 \\
6,650 \\
6,400 \\
5,500 \\
\text { I,400 } \\
\text { I,050 } \\
\text { I,024 } \\
2,000 \\
\text { I,200 } \\
\text { I, } 100 \\
\text { I,000 } \\
\text { I,000 } \\
\text { I, }, 000 \\
160 \\
200 \\
512 \\
512 \\
480\end{array}$ & $\begin{array}{r}80,000 \\
80,000 \\
45,000 \\
40,000 \\
64,000 \\
45,000 \\
36,000 \\
40,000 \\
16,000 \\
14,000 \\
6,000 \\
6,000 \\
5,000 \\
4,750 \\
3,000 \\
3,000 \\
900 \\
600 \\
500 \\
1,100 \\
720 \\
650 \\
600 \\
320 \\
375 \\
60 \\
125 \\
256 \\
256 \\
275\end{array}$ & $\begin{array}{r}\text { I00,000 } \\
96,000 \\
60,000 \\
54,000 \\
80,000 \\
60,000 \\
56,000 \\
56,000 \\
22,000 \\
\text { I 7,000 } \\
8,000 \\
7,500 \\
7,000 \\
5,650 \\
4,000 \\
3,600 \\
\text { I,200 } \\
900 \\
750 \\
\text { I,675 } \\
960 \\
\text { I,050 } \\
900 \\
5 \text { I } 2 \\
512 \\
\text { I } 20 \\
\text { I } 75 \\
43^{2} \\
432 \\
420\end{array}$ \\
\hline
\end{tabular}

found to be most delicate, Hoffmann's and Scherer's tests being used as confirmatory. The unequal delicacy of the reactions employed made it necessary to adopt a rule to secure uniformity in results. Hence only such concentrations were considered inhibiting as gave no results with any test, while the only strengths tabulated as allowing 
action were those that gave unmistakable results with a majority of the tests. Scherer's test-the isolation of leucin and tyrosinwas of course conclusive. The application of this rule resulted in some cases in comparatively wide gaps between the toxic and nontoxic strengths given in the table; e. $g$., $m / 6_{5} \circ \mathrm{Mg}\left(\mathrm{NO}_{3}\right)_{2}$ is given as inhibiting, since it gave none of the tests; $\mathrm{m} / \mathrm{I} 000$ as allowing action, since it gave all; while $m / 850$ gave faint tryptophan reaction but no ScHERER's test, and was therefore disregarded.

In beginning to experiment with a particular salt, a stock solution was first made; a portion of this was diluted to give the greatest strengths desired, and greater dilutions were made from this by successive additions of distilled water. For example, in my first experiment with $\mathrm{CuSO}_{4}$ a series of tubes with $\mathrm{m} / 5000, \mathrm{~m} / \mathrm{I} 0000$, up to $m / 400000$ were made up in duplicate. The results indicated where the critical points-between $m / 50000$ and $m / 100000$-were to be expected, the duplicates preventing error. Closer series were then made and repeated until the limits of toxicity and non-toxicity were clearly determined. Finally the whole table was twice checked over in duplicate, so that the figures given represent in every case from eight to twelve concordant results.

The results obtained may be shown by arranging the metals used in the order of toxicity, beginning with the most poisonous. The results obtained by MaTHEws, working with eggs of Fundulus heteroclitus, and those of McGuigan with diastase are given for purposes of comparison.

$\begin{array}{ccc}\text { Mathews (I4) } & \text { McGuigan (I6) } & \text { Caldwell } \\ \mathrm{Ag} & \mathrm{Ag} & \mathrm{Ag} \\ \mathrm{Hg} & \mathrm{Hg} & \mathrm{Hg} \\ \mathrm{Cu} & \mathrm{Cu} & \mathrm{Cu} \\ \mathrm{Cd} & \mathrm{Cd} & \mathrm{Pb} \\ \mathrm{Pb} & \mathrm{Co} & \mathrm{Zn} \\ \mathrm{Zn} & \mathrm{Zn} & \mathrm{Ba} \\ \mathrm{Co} & \mathrm{Pb} & \mathrm{Cd} \\ \mathrm{Li} & \mathrm{Sr} & \mathrm{Co} \\ \mathrm{Sr} & \mathrm{Ba} & \mathrm{Na} \\ \mathrm{Na} & \mathrm{Mg} & \mathrm{Li} \\ \mathrm{Ba} & \mathrm{Li} & \mathrm{Sr} \\ \mathrm{Mg} & \mathrm{Na} & \mathrm{Mg} \\ \mathrm{NH}_{4} & & \mathrm{NH}_{4} \\ \mathrm{~K} & & \mathrm{~K}\end{array}$


While there are a number of exceptions, these results show a general agreement which is more striking in view of the total lack of harmony in the earlier work with poisons, whether with plants or animals. Silver, mercury, and copper stand at the head of the three lists. In my experiments, cadmium stands near zinc, nearly in the place it should occupy in accordance with the theory of Mathews, who found it in his work only less poisonous than copper. Mathews and McGuigan have found sodium less poisonous than lithium or strontium, using the chlorids. I find the three sulfates practically equal in toxicity, while sodium nitrate is much more poisonous than the other nitrates. My results agree more nearly with those of Mathews in the places given lithium, lead, and cobalt. The great toxicity of barium in my experiments cannot be attributed to impurities in the salts used or to inaccuracy in performing the experiments, since several standard preparations gave markedly uniform results, and the series has been worked over so many times that the possibility of mistake is excluded.

The nitrates uniformly inhibit the action of the enzyme in somewhat greater dilution than the corresponding sulfates and chlorids, which agree very closely.

The action of the enzyme is markedly weaker and is uniformly inhibited by poisonous solutions of less concentration than when acting in alkaline media. This confirms the evidence already given for the existence of two enzymes.

\section{EXPERIMENTS UPON AUTODIGESTION.}

The experiments upon autodigestion were suggested by the discovery that while none of the tests for peptones, leucin, or tyrosin were given by freshly prepared aqueous solutions of the impure enzyme, all these were present in such solutions after standing for

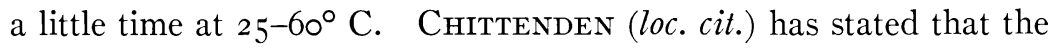
proteids of the juice are exceedingly resistant to the action of the enzymes, while VINES $(\mathbf{2 5}, e)$ has mentioned the occurrence of autodigestion in the expressed juice. My own observations led to the supposition that the associated proteids were acted upon by the enzyme at suitable temperatures. This was found to be true of acid and alkaline solutions, not of neutral ones. The associated proteid 
was first rapidly digested, the breaking down of the enzyme itself proceeding more slowly and continuing until complete.

Solutions containing $\mathrm{I}^{\mathrm{gm}}$ each of the impure enzyme were placed in the water-bath and kept at $40^{\circ} \mathrm{C}$. for 12 days, the growth of bacteria being prevented by the addition of thymol. At short intervals, portions were removed and examined for digestion products by all the methods employed in other experiments. Traces of peptones, leucin, and tyrosin were found after $\mathrm{I} \frac{1}{2}$ hours, rapidly increased in amount for IO-I4 hours, then very slowly increased for 9-10 days. During the first day, portions were hourly removed, filtered, and tested as to their activity upon egg-albumen, no perceptible decrease in power being shown. After the first day, portions were removed once or twice daily and tested, and there was found a decrease in power to digest egg-albumen proceeding pari passu with the increase of digestion products in the stock solution, until after the eighth day no perceptible action upon egg-albumen occurred, even after prolonged standing. Contrary to my expectation, the process of autodigestion was not checked or inhibited by the accumulation of its products, since it was equally rapid in the stock solution and in another from which the digestion products were daily removed. Furthermore, the two enzymes break down with equal rapidity, since activity in acid and alkaline media decreased equally until the eighth day, after which no action occurred.

No such decrease in activity occurred, nor were digestive products present, in purer preparations of the enzyme kept for a much longer period (five weeks) under similar conditions, nor were such solutions affected by light.

It was hoped that a preparation purer than I had otherwise been able to make might be obtained by allowing the digestion to proceed until the associated proteid had been broken down, separating the products of digestion from the enzyme and drying the latter. To my surprise, digestion immediately began in aqueous solutions made from such a preparation, and would occur perceptibly in the moist precipitate while drying in a calcium chlorid desiccator.

Autodigestion does not begin so long as there are present proteids, either egg-albumen, fibrin, or that present in the juice, but does begin as soon as these have been broken up. 
Autodigestion occurs most rapidly in alkaline solutions equaling $m / 16-m / 3^{2} \mathrm{KOH}$ or $\mathrm{NaOH}$, less rapidly in $m / \mathrm{Io}-m / 24 \mathrm{HCl}, \mathrm{H}_{2} \mathrm{SO}_{4}$, or $\mathrm{HNO}_{3}$. Action was inhibited by greater concentrations and occurred more slowly in weaker ones. It occurs with poisons in strengths very much greater than those inhibiting the action of purer preparations upon egg-albumen, as shown by the following table:

Autodigestion in $m / 24 \mathrm{HCl}$ AT $40^{\circ} \mathrm{C}$.

\begin{tabular}{|c|c|c|}
\hline \multirow{2}{*}{ SALT } & \multicolumn{2}{|c|}{ DiLUTiON OF MOLECULAR SOLUTION } \\
\hline & Inhibited & Allowed \\
\hline 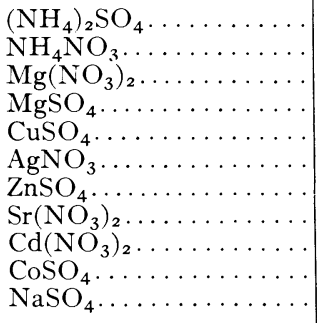 & $\begin{array}{r}72 \\
48 \\
\text { I } 28 \\
\text { I00 } \\
6,000 \\
\text { I } 6,000 \\
\text { I0,000 } \\
600 \\
5 \text { I } 2 \\
\text { I,600 } \\
\text { I } 50\end{array}$ & $\begin{array}{r}\text { I } 20 \\
64 \\
256 \\
\mathrm{I} 75 \\
8,650 \\
22,750 \\
\mathrm{I} 6,000 \\
800 \\
768 \\
2,400 \\
225\end{array}$ \\
\hline
\end{tabular}

In an alkaline medium $(m / 32 \mathrm{NaOH})$, inhibiting and allowing strengths were uniformly about one-third greater with the few salts tested.

The table just given also represents pretty closely the conditions for the digestion of egg-albumen by such impure preparations, in so far as this was studied. For example, digestion would just occur in $m / \mathrm{I}_{4} 000 \mathrm{ZnSO}_{4}, m / 7200 \mathrm{CuSO}_{4}$, or $m / \mathrm{I} 800 \mathrm{Co}\left(\mathrm{NO}_{3}\right)_{2}$, as determined by decrease in the amount of albumen subjected to the test. Hence the degree of susceptibility to poisons is determined largely by the purity of the preparation employed, apparently because the enzyme is shielded by the associated proteid from the action of poisons. The results obtained with preparations of varying purity are parallel, $i$. e., the toxic strengths of different metals bear approximately the same relation to each other irrespective of the preparation used.

\section{SUMMARY.}

I. Impure preparations of bromelin are strongly autodigestive in acid or alkaline media, such digestion beginning when the breaking up of proteid impurities has been completed and proceeding to total destruction of the enzyme. 
2. The effects of poisons vary with the purity of the preparation used, slight amounts of proteid impurities rendering necessary an enormous increase of concentration in order to inhibit action.

3. The toxic strengths of the salts used maintain a constant relationship irrespective of the purity of the enzyme used, $i$. e., silver is always most poisonous, copper third, zinc sixth, and so on.

4. Bromelin, when prepared in a relatively pure condition is not at all autodigestive, the presence of some proteid of the juice apparently being a prerequisite for such action.

5. Such preparations appear to be in reality a mixture of two enzymes, one active in alkaline solutions, slightly more resistant to poisons, and twice as great in amount as the other, which is active in acid media and is destroyed by heating to $65^{\circ} \mathrm{C}$. in saline solution.

6. The limits of toxicity and non-toxicity are somewhat more clearly defined than has been the case in experiments upon living organisms (5, I 1, 12, 18, 19, 25).

7. The results obtained agree in general with Mathews's arrangement of the metals upon the theory that "the affinity of the atom or ion for its electrical charge is the main factor determining its physiological action." Cadmium in my experiments occupies the position it should hold in accordance with this theory, while barium is far out of place.*

My sincere thanks are due to Dr. B. E. Livingston, at whose suggestion the work was begun, for much help in its inception, and to Dr. C. R. Barnes for assistance in its progress and completion.

* Experiments undertaken in order to determine more conclusively the place to be given barium are still in progress. I have found it only relatively less poisonous than zinc in every case, whether bromelin, papäin, or animal trypsin were the enzyme used.

The. Unive Rsity of Chicago.

\section{LITERATURE CITED.}

I. Bourquelot, Les fermentations. Paris. I893.

2. Chittenden, Mendel, and McDermotr, Papäin proteolysis. Am. Jour. Physiol. I:255. 1898 .

3. Chittenden, R. H., The enzyme of the pineapple. Trans. Conn. Acad. $8: 36$. 189 r.

4. - The enzyme of the pineapple. Jour. Physiol. 15:290. r894. 
5. Clark, J. B., On the toxic effects of deleterious agents. Bot. Gazette 28:289. I899.

6. Coles, S. W., Contributions to our knowledge of enzyme action. I. Influence of electrolytes on the action of amylolytic ferments. Jour. Physiol. 30 : 202. I903. II. Influence on invertin ibid.30:28I. I903.

7. Duclaux, Traité de biologie. Paris. 1896.

8. Effront, L., Les enzymes et leurs applications. Paris. I899.

9. Green, J. R., The soluble ferments and fermentation. I899.

I0. Guitzner, Archiv. Gesam. Physiol. 91 : 145. 1902.

II. Kahlenberg and True, On the toxic action of dissolved salts. Bot. Gazette 22:8I. I896.

12. Kanda, M., Studien über die Reizwirkung einiger Metallsalze auf das Wachstums höherer Pflanzen. Jour. Coll. Sci. Imp. Univ. Tokyo I9: Art. I3. pp. 37. pl. I. I904.

I3. Marcano, Bull. of Pharmacy 5:77. I89I.

14. Mathews, A. P., Relation between solution tension, atomic volume, and physiological action of the elements. Am. Jour. Physiol. Io: 290. I904.

I5. ——_ Nature of chemical and electrical stimulation. ibid.I I : 455. I904.

16. McGuigan, Am. Jour. Physiol. Io:444. I904.

17. Neilson, C. H., and Brown, O. H., Effect of ions on the hydrolysis of butyric ether by watery extracts of the pancreas. Am. Jour. Physiol. Io: 335 . I904.

18. Ono, N., Ueber die Wachsthumsbeschleunigung einiger Algen und Pilze durch chemische Reize. Jour. Coll. Sci. Imp. Univ. Tokyo I3: I4I-I56. pl. I3. I900.

19. Richards, H. M., Die Beeinflussung des Wachsthums einiger Pilze durch chemische Reize. Jahrb. Wiss. Bot. 30:665-688. I897.

20. Rideal, O. S., Papäin digestion. Pharm. Jour. III. 24:845. I 894.

2I. Roberts, E. N., The digestive ferments. Lumliean Lectures. I880.

22. Sharp, Gordon, Papäin digestion. Pharm. Jour. III. 24:633. I893.

23. Schützenberger, Les fermentations. Paris. I 896.

24. Stevens, F. L., The effect of aqueous solutions upon the germination of fungus spores. Bot. Gazette 26:377. I897.

25. Vines, S. H., Proteolytic enzymes of Nepenthes. (a) Ann. Botany Io: 292. I896; (b) I I:563. I897; (c) I2:548. I898; (d) I5:I. I902; (e) I5: 563. 1902 .

26. Vernon, H. M., Conditions for the action of pancreatic ferments. Jour. Physiol. 26:405. I901 et seq. 